\title{
Oestrogen and progesterone receptor immunoreactivity and c-fos expression in the ovine cervix
}

\author{
Y. Zhao ${ }^{1,2 *}$, L. M. Williams ${ }^{2+}$, L. T. Hannah ${ }^{2}$, A. W. Ross ${ }^{2}$, W. A. C. McKelvey ${ }^{3}$ and J. J. Robinson ${ }^{1}$ \\ 'Scottish Agricultural College, Craibstone, Aberdeen AB21 9YA, UK; ${ }^{2}$ Rowett Research Institute, Bucksburn, Aberdeen AB2 9SB, UK; \\ and ${ }^{3}$ Scottish Agricultural College, Bush Estate, Penicuik EH26 OPH, UK
}

\begin{abstract}
Immunocytochemistry was used to detect the presence of oestrogen and progesterone receptors in the cervices of prepubertal lambs, seasonally anoestrous ewes, cyclic ewes, and pregnant ewes of known gestational stages, to define the roles of gonadal steroids in cervical function. The presence of the immediate early gene product, c-Fos, a marker for cellular activation, was also investigated using immunocytochemistry and in situ hybridization. Oestrogen receptor immunoreactivity was restricted to the endometrium on days $0-3$ of the oestrous cycle (day $0=$ oestrus). In immature animals, very few scattered nuclei in the endometrium were immunoreactive. Oestrogen receptor immunoreactivity was not apparent in the endometrium during the remainder of the oestrous cycle or in this region in anoestrous animals. In pregnant ewes, oestrogen receptor immunostaining appeared as relatively few isolated nuclei in the connective tissue stroma. Progesterone receptor immunoreactivity was found in the endometrium at days $0-3$ of the oestrous cycle and also in the luminal epithelium, the myometrium and the blood vessels. Progesterone receptor immunoreactivity was also found in these regions, with the exception of the endometrium, at all other stages examined. Immunostaining for c-Fos was present in the endometrium at days $0-3$ of the oestrous cycle, and some scattered immunopositive nuclei were present in prepubertal animals. c-Fos immunoreactivity was also found in the myometrium and in blood vessels at all other stages examined. Visualization of c-fos gene expression by in situ hybridization showed that it occurred in the luminal epithelium and blood vessels at oestrus, but was restricted to the blood vessels in all other samples examined.
\end{abstract}

\section{Introduction}

The cervix acts as a protective barrier for the upper genital tract in non-pregnant females and prevents expulsion of the conceptus throughout pregnancy while permitting the passage of the offspring at parturition. Fulfilling these diverse roles involves major changes in both the function and the form of the cervix (Dobson, 1988). The factors that control the function of the ovine cervix are poorly understood, but like most of the female reproductive tract, it is thought that ovarian steroids are important.

Ovarian steroid hormones regulate development, growth, proliferation and differentiation of reproductive tissues through their specific receptors (Clark and Mani, 1994). The number of steroid receptors varies depending on the steroidal milieu. Oestradiol and progesterone are known to alter the expression of oestrogen receptors (Bergman et al., 1992; Clark and Mani, 1994; Perrot-Applanat et al., 1994).

* Present address: Florida Institute for Reproductive Medicine, Baptist Medical Centre Pavilion, 386 Prudential Drive, Suite 902, Jacksonville, FL 32207, USA.

tCorrespondence.

Received 16 June 1998
Oestradiol also influences the expression of progesterone receptors (Blaustein and Turcotte, 1989; Chauchereau et al., 1992; Clark and Mani, 1994). In the ovine uterus, the populations of oestrogen and progesterone receptors change markedly during the oestrous cycle (Cherny et al., 1991; Wathes and Hamon, 1993). Consequently, the influence of oestradiol and progesterone varies in different stages of the oestrous cycle and also in different tissues (Wathes and Hamon, 1993).

The aim of this study was to investigate the role of oestrogen and progesterone in the function of the ovine cervix. Oestrogen and progesterone receptors in the cervix of animals with different steroidal backgrounds were mapped using immunocytochemistry. Tissue was examined from immature animals, seasonally anoestrous animals, cyclic animals, and animals in late pregnancy. c-Fos expression in the ovine cervix was also investigated in serial sections from the same animal by in situ hybridization and immunocytochemistry. Stimulation of cells by oestrogen has been linked to the expression of the immediate early gene product, c-Fos; oestradiol induces expression of c-fos mRNA in the rat uterus (Nephew et al., 1995). In addition, c-fos 
expression correlates with the proliferative response in the oestrogen-stimulated immature uterus (Boettger-Tong $e t$ al., 1995). The possible relationship between the presence and activation of oestrogen receptors and the induction of c-fos was investigated in the ovine cervix. The use of immunocytochemistry and in situ hybridization provides a direct comparison between tissues that express oestrogen and progesterone receptors and c-fos.

\section{Materials and Methods}

\section{Animals}

Ovine (Suffolk crossbred) cervical tissues were obtained from pre-pubertal lambs $(n=2)$, seasonally anoestrous ewes $(n=4)$ and cyclic ewes $(n=14)$ that had been killed at an abattoir. The stage of the oestrous cycle in the cyclic ewes was confirmed at death by visual inspection of the ovaries and corpora lutea as described by Oldham and Lindsay (1980). Pregnant ewes $(n=6)$ at a known gestational stage (125 and 135 days) were killed by barbiturate overdose $\left(0.5 \mathrm{ml} \mathrm{kg}^{-1}\right.$ i.v. $)$ and cervices were collected. All procedures complied with the Animals (Scientific Procedures) Act of 1986. Tissue was rapidly frozen in isopentane over dry ice and stored at $-70^{\circ} \mathrm{C}$. Cryostat sections $(20 \mu \mathrm{m})$ were taken from the mid-region of the cervix and thaw mounted onto gelatin-coated slides for immunocytochemistry or onto gelatin poly(L-lysine)-coated slides for in situ hybridization.

\section{Immunocytochemistry}

Cryostat sections were fixed overnight in acetone at $-80^{\circ} \mathrm{C}$, transferred to $-20^{\circ} \mathrm{C}$ for $1 \mathrm{~h}$, and incubated in $1 \%(\mathrm{w} / \mathrm{v}) \mathrm{BSA}$ for $20 \mathrm{~min}$ at room temperature to reduce non-specific binding. Sections were then incubated for $18 \mathrm{~h}$ at $4^{\circ} \mathrm{C}$ with

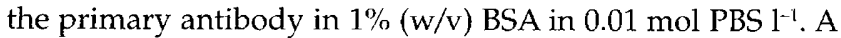
polyclonal antibody raised against the rat oestrogen receptor (Department of Health and Human Services, National Institute of Health, Bethesda, MD) was used at a dilution of 1:1000. A polyclonal anti-human progesterone receptor (NCL-PGRp) (Novocastra Laboratories Ltd, Newcastle upon Tyne) was used at a dilution of 1:800 dilution, and a polyclonal antibody raised against a synthetic peptide derived from the N-terminal region of c-Fos (Biochemistry of the Cell Nucleus Laboratory, Imperial Cancer Research Fund, London) was used at a dilution of 1:500. Sections were then washed in $0.01 \mathrm{~mol} \mathrm{PBS} \mathrm{l}^{-1}(2 \times 5 \mathrm{~min})$ and incubated with polyclonal anti-rabbit IgG peroxidase conjugate (Sigma International, Poole) diluted 1:500 in $1 \%(\mathrm{w} / \mathrm{v}) \mathrm{BSA}$ in 0.01 mol PBS l-1 for $2 \mathrm{~h}$. Slides were then washed $(2 \times 5 \mathrm{~min})$ in $0.01 \mathrm{~mol} \mathrm{PBS}^{-1}$. The colour reaction was developed using a vector peroxidase substrate kit (Vector Laboratories, Peterborough). Control sections were incubated as described above with the exception that the primary antibody was replaced by normal rabbit serum. Sections were then rinsed in distilled water, lightly counterstained with neutral red, dehydrated and mounted.

\section{In situ hybridization}

Cryostat sections were fixed in $4 \%(\mathrm{w} / \mathrm{v})$ paraformaldehyde in $0.1 \mathrm{~mol} \mathrm{PBS} 1^{-1}$ for $20 \mathrm{~min}$ on ice. After washing in $0.5 \mathrm{~mol} \mathrm{PBS} \mathrm{l}^{-1}(2 \times 5 \mathrm{~min})$, slides were treated in $0.1 \mathrm{~mol}$ triethanolamine (TEA) $\mathrm{l}^{-1}$ for $2 \mathrm{~min}$, followed by 0.1 mol TEA $\mathrm{l}^{-1}$ and $0.25 \%(\mathrm{v} / \mathrm{v})$ acetic anhydride for $10 \mathrm{~min}$. Slides were then washed in PBS $(2 \times 2 \mathrm{~min})$, dehydrated in a graded series of ethanol and dried under vacuum for $60 \mathrm{~min}$. The slides were incubated with $80 \mu 1$ hybridization solution for $18 \mathrm{~h}$ at $60^{\circ} \mathrm{C}$. The $\mathrm{cRNA}$ probe was produced using a 684 bp fragment of the mouse $\mathrm{v}$-fos gene (Beatson Cancer Research Institute, Glasgow) which was directionally cloned into pBluescript SK. The cRNA probe was labelled with [ ${ }^{35}$ S]UTP and linearized with Pst 1 to generate antisense transcripts using T7 polymerase and linearized with Sal 1 to generate sense transcripts using T3 polymerase. The hybridization solution was composed of $50 \% \quad(\mathrm{v} / \mathrm{v})$ formamide, $0.3 \mathrm{~mol} \mathrm{NaCl} \mathrm{l}^{-1}, 1 \times$ Denhardt's solution, 10 mmol Tris $~^{-1}, 1$ mmol EDTA $~^{-1}, 0.05 \%(\mathrm{v} / \mathrm{v})$ yeast transfer RNA, $10 \mathrm{mmol}$ dithiothreitol $\mathrm{l}^{-1}$ and $10 \%(\mathrm{w} / \mathrm{v})$ dextran sulphate. After hybridization, sections were washed in several changes of $4 \times$ saline-sodium citrate (SSC), $2 \times$ SSC, 1 $\times$ SSC, $0.5 \times$ SSC and $0.1 \times$ SSC, treated with RNase A and dehydrated in ethanol. Air dried slides were then apposed to Hyperfilm $\beta$-max film (Amersham International, Little Chalfont, Amersham) for 5 days at room temperature, or coated with LM-1 liquid film (Amersham International, Little Chalfont, Amersham). The sections were then stained in toluidine blue and mounted for conventional photography. Photographic negatives were then scanned using a UMAX Power Look II scanner (UMAX Technologies Inc., Fremont, CA), processed using Adobe Photoshop (Adobe Systems Inc., San Jose, CA) and printed on a Tektronix Phaser dye sublimation printer (Tektronix Inc., Wilsonville, OR). All chemicals were supplied by Sigma International, Poole, unless otherwise indicated.

\section{Results}

\section{Oestrogen receptors}

There was marked variation in oestrogen receptor immunoreactivity in the cervix in the different groups of animals examined. During oestrus (day 0), strong nuclear staining was observed in the endometrium (Fig. 1a). The nuclear staining was also present on days 1,2 and 3 of the oestrous cycle and appeared to be of a similar intensity and localization (not shown). Oestrogen receptor immunoreactivity was absent for the remainder of the oestrous cycle (not shown). Relatively few scattered immunopositive nuclei were observed in the endometrium of the prepubertal cervix (Fig. 1b) and no immunopositive nuclei were observed in the cervices of seasonally anoestrous animals (Fig. 1c). Oestrogen receptor immunoreactivity was not observed in the endometrium on days 125 and 135 of pregnancy (Fig 1d), but very few isolated nuclei were found in the myometrium and surrounding connective tissue (not shown). 

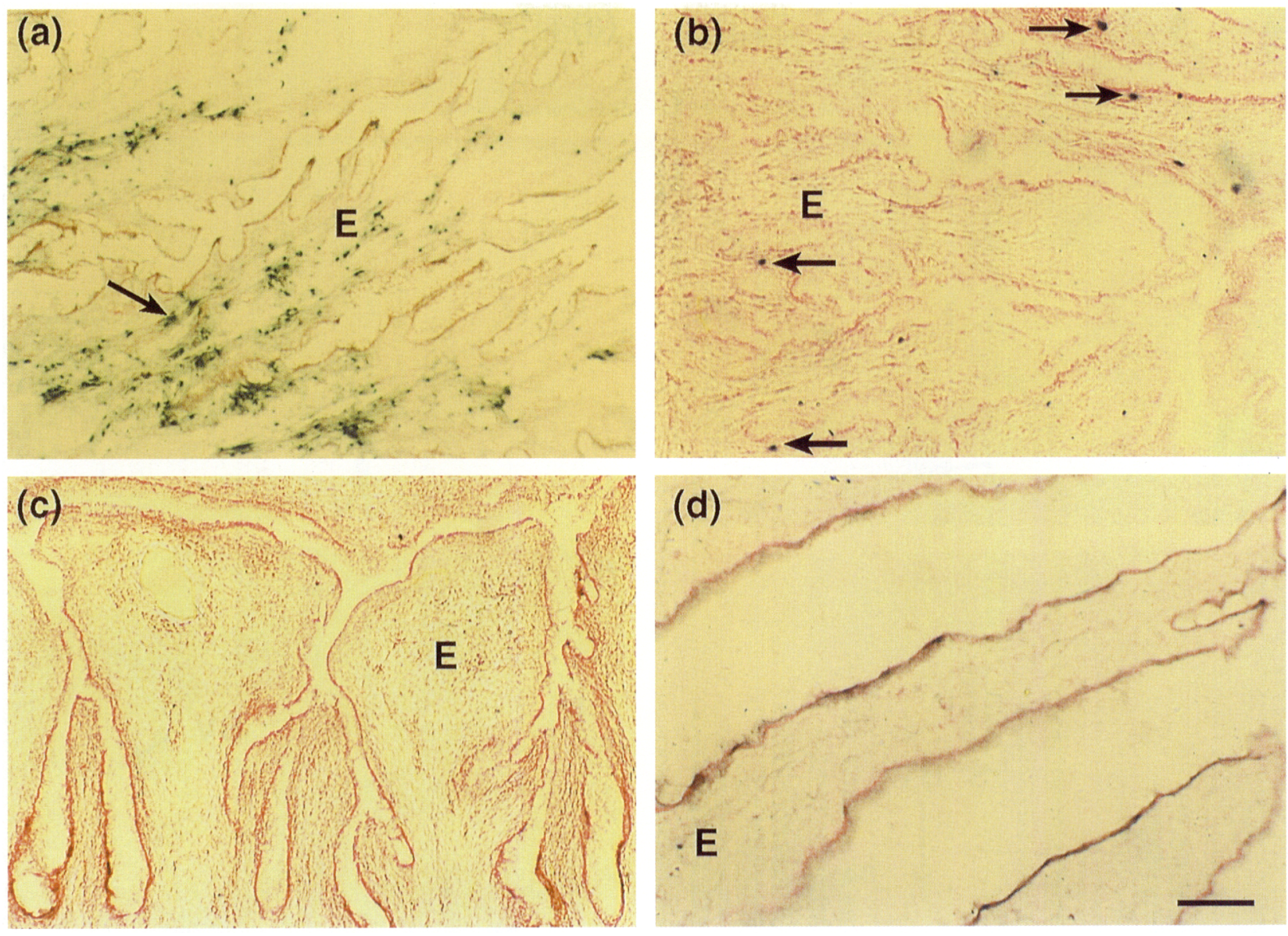

Fig. 1. Oestrogen receptor immunoreactivity in the ovine cervix. (a) Immunopositive nuclei (blue-grey in colour; see arrow) occur in the endometrium (E) at oestrus. (b) Scattered immunopositive nuclei (arrows) are observed in the endometrium of an immature animal. No immunopositive nuclei are found in the endometrium (c) during seasonal anoestrus or (d) during late pregnancy (125 days of gestation). Results are representative of four independent experiments. Scale bar represents $200 \mu \mathrm{m}$.

\section{Progesterone receptors}

Progesterone receptor immunoreactivity was present in the nuclei of the endometrium (Fig. 2a) at oestrus and up to day 3 of the oestrous cycle, and also appeared in the cytoplasm of the luminal epithelium, myometrium and blood vessels (not shown). Staining was not apparent in the endometrium during the later stages of the cycle, but remained present in the nuclei and cytoplasm of the myometrium and blood vessels (not shown). Positive staining was also observed in the myometrium, luminal epithelium and blood vessels in anoestrous ewes (Fig. 2b). During late pregnancy (days 125 and 135) positive staining was observed in myometrium, blood vessels (not shown) and the luminal epithelium (Fig. 2c).

\section{$c$-Fos localization and gene expression}

c-Fos localization and gene expression in the ovine cervix were investigated by immunocytochemistry and in situ hybridization. c-Fos immunoreactivity was restricted to the endometrium of the cervix on days $0-3$ of the oestrous cycle
(Fig. 3a). No c-Fos immunoreactivity was apparent in this region during the later stages of the oestrous cycle or during anoestrus (not shown). In all samples examined, immunostaining could be observed in the myometrium and blood vessels (Fig. 3b). In situ hybridization revealed that c-fos mRNA occurred at oestrus in the luminal epithelium but not in the endometrium (Fig. 4a). No specific signal for expression of the c-fos gene was observed in the luminal epithelium on other days of the cycle, in immature animals, or during anoestrus or late pregnancy. However, a signal was apparent in endothelial cells of blood vessels in all samples examined (Fig. 4b-d).

\section{Discussion}

The structure and appearance of the cervix changes markedly during the oestrous cycle, pregnancy and parturition, and there appears to be a temporal relationship between these changes and the changes in circulating concentrations of oestradiol and progesterone (Fitzpatrick and Dobson, 1979). In sheep, oestradiol induces changes in the mechanical strength of the cervix (Fitzpatrick and 

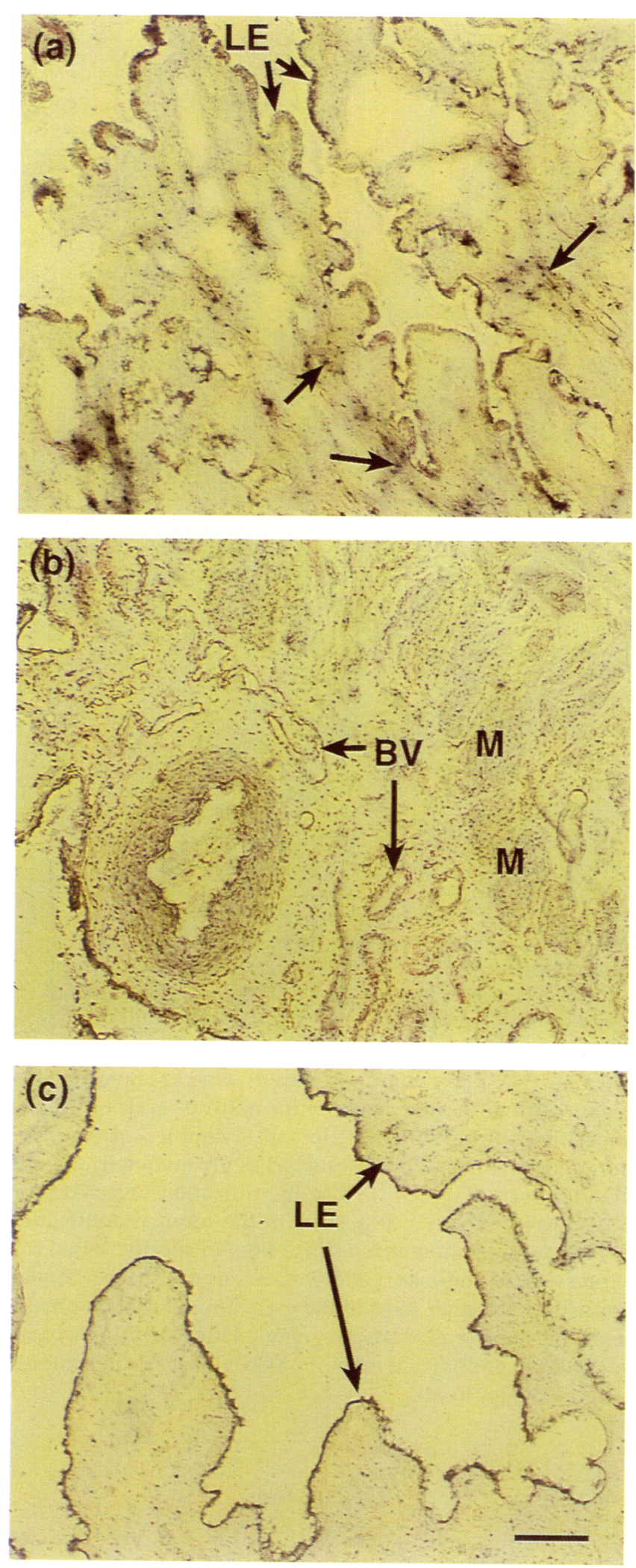

Fig. 2. Progesterone receptor immunoreactivity in the ovine cervix. (a) Immunopositive nuclei (blue-grey in colour; see arrows) occur in the endometrium at oestrus; the luminal epithelium is also positive. (b) Immunopositive staining in seasonal anoestrus in the myometrium and blood vessels resembles that found at all other
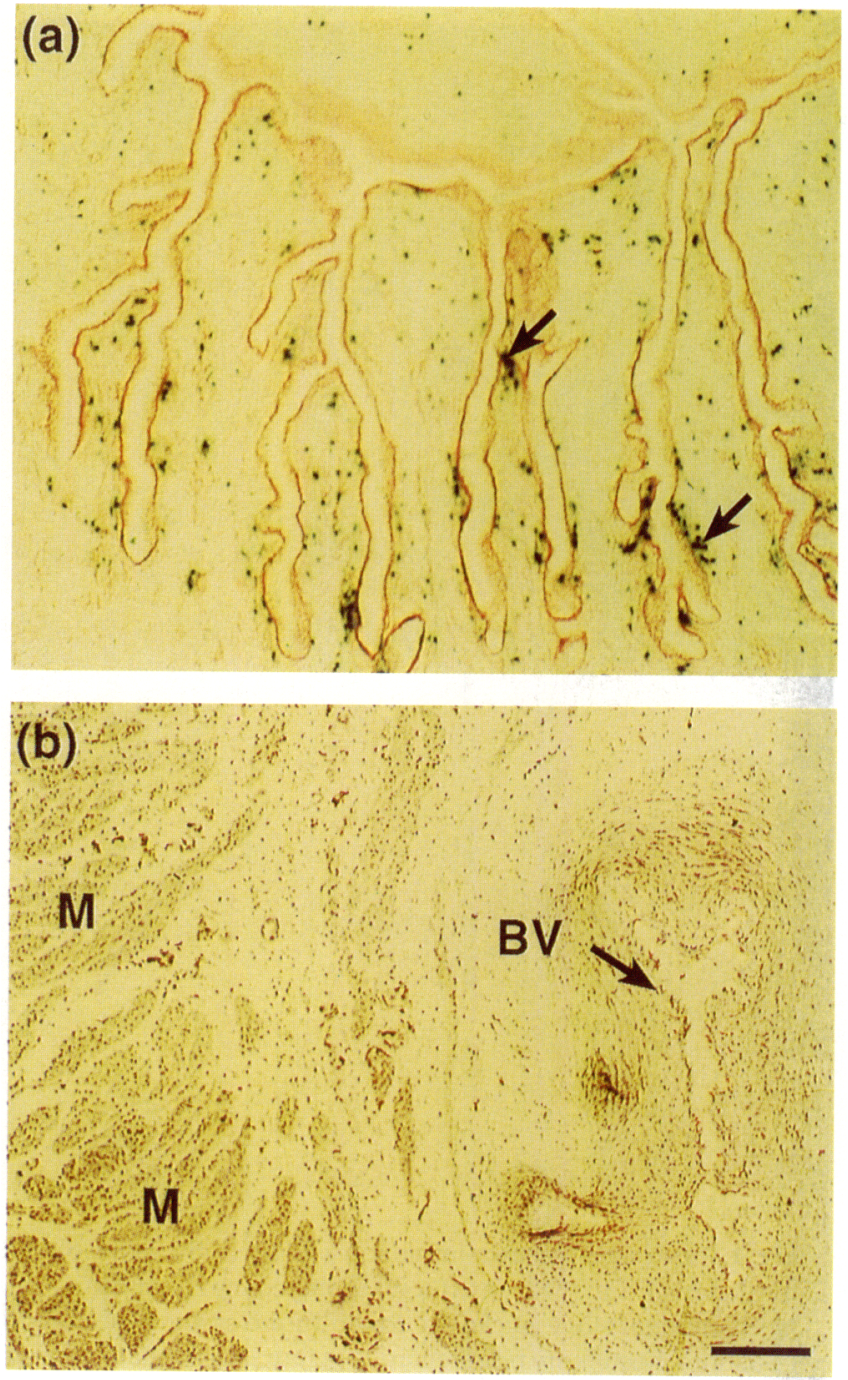

Fig. 3. c-Fos immunoreactivity in the ovine cervix. (a) Immunopositive nuclei (blue-grey in colour; see arrows) occur in the endometrium at oestrus. (b) Immunopositive staining in the myometrium (M) and blood vessels (BV) at seasonal anoestrus. Scale bar represents $150 \mu \mathrm{m}$.

Dobson, 1981). However, the full role of steroid hormones in cervical function is not clear.

In the present study, oestrogen receptors were detected in the endometrium of the ovine cervix. This finding correlates strongly with the expected peak in serum oestradiol concentrations (Hauger et al., 1977; Legan and Karsch, 1979), and is in accordance with the observation that oestrogen and progesterone receptors are at maximum concentrations in all regions of the ovine reproductive tract at oestrus (Wathes and Hamon, 1993). The absence of oestrogen receptor immunoreactivity in the ovine cervical endometrium during the remainder of the oestrous cycle may be the result of

stages examined. (c) Immunopositive staining in the luminal epithelium at day 125 of pregnancy. Results are representative of three independent experiments. BV, blood vessels; LE, luminal epithelium; M, myometrium. Scale bar represents $200 \mu \mathrm{m}$. 

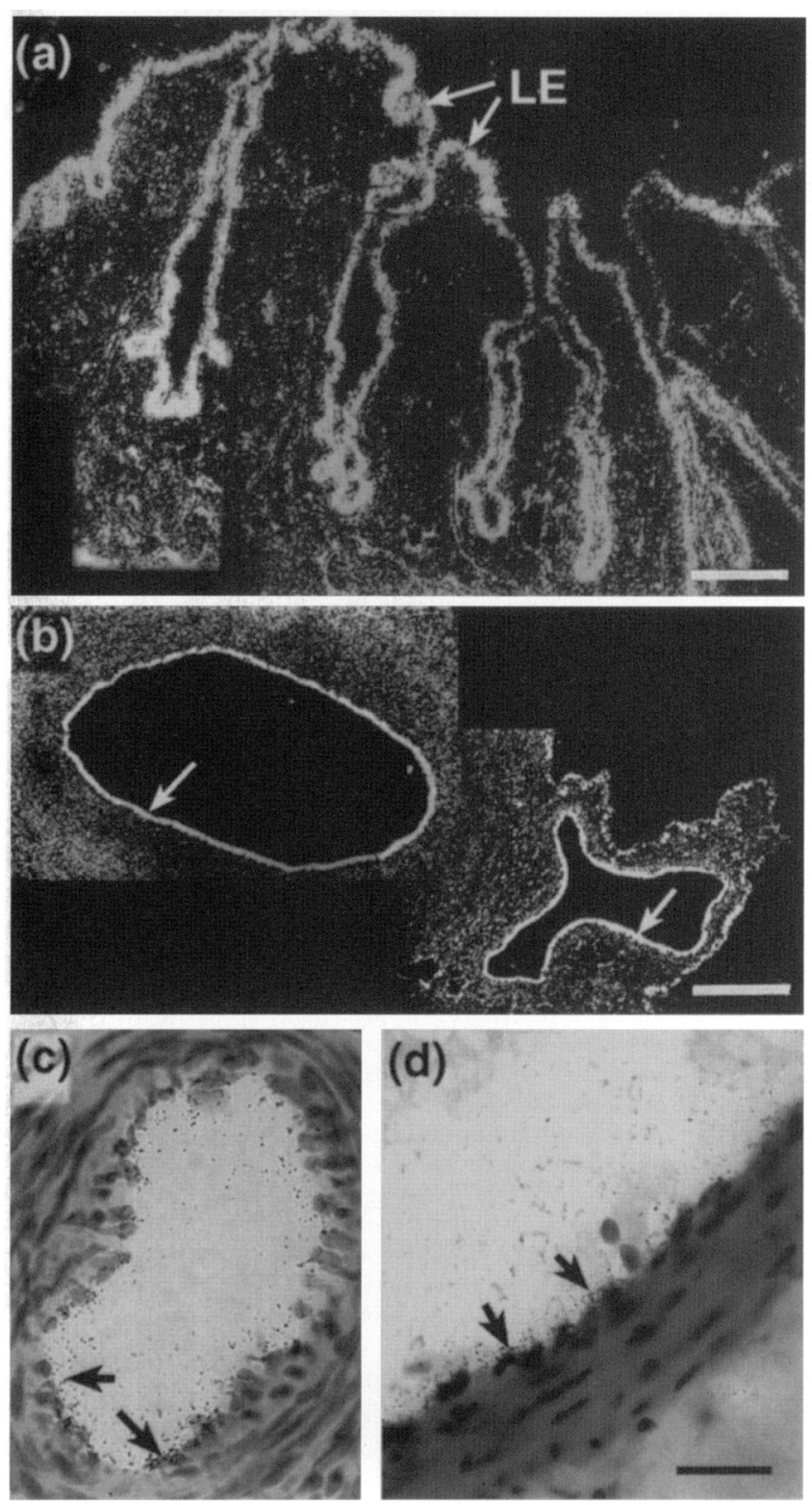

Fig. 4. c-fos gene expression in the ovine cervix as revealed by in situ hybridization. (a) Dark-field micrograph showing c-fos expression (arrows) in (a) the luminal epithelium (LE) at oestrus and (b) in blood vessels at seasonal anoestrus. (c,d) Light-field micrographs showing silver grains (arrows) associated with the endothelial cells of blood vessels. Results are representative of three independent experiments. Scale bars represent (a) $70 \mu \mathrm{m}$, (b) $100 \mu \mathrm{m}$, (c,d) $50 \mu \mathrm{m}$.

reduced circulating oestradiol concentrations or increased progesterone concentrations. Oestradiol upregulates the number of oestrogen receptors (Bergman et al., 1992; Clark and Mani, 1994), while progesterone downregulates the number of oestrogen receptors (Clark and Mani, 1994; Perrot-Applanat et al., 1994).

Progesterone receptor immunoreactivity in the cervical endometrium at oestrus also correlates well with increased serum oestradiol and low serum progesterone concentrations at this stage (Legan and Karsch et al., 1979). Progesterone receptor immunoreactivity persists in the luminal epithelium, the myometrium and the vascular epithelium of the cervix and is not coincident with oestrogen receptor immunoreactivity, indicating a fundamental difference in the regulation of progesterone receptors between these regions and the endometrium. Oestradiol upregulates the number of progesterone receptors (Chauchereau et al., 1992; Clark and Mani, 1994), and this effect is specific to oestrogen receptive cells in the brain (Blaustein and Turcotte, 1989). This implies that, in the cervical endometrium, progesterone receptor expression is increased by oestradiol and that progesterone and oestrogen receptors are present in the same cells within this region. An increase in progesterone concentration may also result in the downregulation of progesterone receptors in the cervical endometrium during the luteal phase (Clark and Mani 1994; Perrot-Applanat et al., 1994). Progesterone receptors in the myometrium of the ovine uterus persist throughout the oestrous cycle, as in the cervix (Wathes and Hamon, 1993). The presence of progesterone receptors in muscle and blood vessels reflects the potential importance of progesterone in the growth and development of the cervix.

Expression of $c-f_{0 s}$ is induced by oestrogen (LooseMitchell et al., 1988; Weisz and Bresciani, 1988; Weisz and Bresciani, 1993). Several groups have reported the presence of oestrogen response elements in the regulatory region of the c-fos gene (Weisz and Rosales, 1990; Hyder $e$ t al., 1991). In the present study, immunoreactive c-Fos was found in the endometrium of the cervix at oestrus, which correlates with peak concentrations of circulating oestradiol and the presence of both oestrogen and progesterone receptors in this region. This observation indicates that the expression of c-Fos in the endometrium is related to the activation of oestrogen receptors. However, c-fos gene expression was not detected at oestrus by in situ hybridization. This is almost certainly due to the rapid turnover of c-fos mRNA, which is only expressed for a limited period, while c-Fos protein is more stable. These results are in agreement with a study of $c-$ fos expression and immunoreactivity in the ovine uterus throughout the oestrous cycle, in which gene expression occurred only at oestrus, but the protein persisted for several days after gene expression became undetectable (Johnson $c t$ al., 1997). c-fos mRNA was found consistently in blood vessels, and its presence may be linked to that of progesterone receptors. However, many endocrine and paracrine factors influence blood vessel function, particularly in tissues that have the potential to undergo rapid remodelling, such as the cervix. The presence of c-fos gene expression in the vasculature of the cervix could be the result of any one of these factors (Rivera and Greenburg, 1990; Hyman et al., 1993)

In summary, the results of the present study show that the number of oestrogen and progesterone receptors in the endometrium of the ovine cervix is modulated during the oestrous cycle. Oestrogen receptors are mainly restricted to the endometrium and are consistently either absent or present in relatively low concentrations, with the exception of oestrus, during which period their expression is much more pronounced. Progesterone receptors are also present in blood vessels and in the myometrium. In the present study, progesterone receptors were expressed in these tissues at all 
the stages examined. Therefore, the mechanisms controlling the expression of progesterone receptors in the endometrium differ from those controlling their expression in other areas of the cervix. The presence of oestrogen and progesterone receptors in the endometrium appears to correlate with c-Fos immunoreactivity.

This work was supported by the Scottish Office Agriculture, Environment and Fisheries Department as part of a Flexible Funding Award. The authors would like to thank David C. Hancock for providing the c-Fos antibody, David Gilespie for providing the c-fos probe, and Bob Duthie for expert assistance with graphics.

\section{References}

Bergman MD, Schachter BS, Karelus K, Combatsiaris EP, Garcis EP and Nelson JF (1992) Up-regulation of the uterine estrogen receptor and its messenger ribonucleic acid during the mouse estrous cycle: the role of estradiol Endocrinology $1301923-1930$

Blaustein JD and Turcotte JC (1989) Estradiol-induced progestin receptor immunoreactivity is found only in estrogen receptor-immunoreactive cells in guinea pig brain Neuroendocrinology 49 454-461

Boettger-Tong HL, Murthy L and Stancel GM (1995) Cellular pattern of c-fos induction by estradiol in the immature rat uterus Biology of Reproduction 53 1398-1406

Chauchereau A, Savouret JF and Milgrom E (1992) Control of biosynthesis and post-transcriptional modification of the progesterone receptor Biology of Reproduction 46 174-177

Cherny RA, Salamonsen LA and Findlay JK (1991) Immunocytochemical localization of oestrogen receptors in the endometrium of the ewe Reproduction Fertility and Development 3 321-331

Clark JH and Mani SK (1994) Actions of ovarian steroid hormones. In The Physiology of Reproduction pp 1011-1062 Eds E Knobil and JD Neill. Raven Press, New York

Dobson H (1988) Softening and dilation of the uterine cervix. In Oxford Review of Reproductive Biology Vol. 10 pp 491-514 Ed. JR Clark. Oxford University Press, Oxford

Fitzpatrick RJ and Dobson H (1979) The cervix of the sheep and goat during parturition Animal Reproduction Science 2 209-224

Fitzpatrick RJ and Dobson H (1981) Softening of the ovine cervix at parturition. In The Cervix in Pregnancy and Labour: Clinical and Biochemical
Investigations pp 40-56 Eds DA Ellwood and ABM Anderson. Churchill, Edinburgh

Hauger RL, Karsch FJ and Foster DL (1977) A new concept for control of the oestrous cycle of the ewe based on the temporal relationships between luteinizing hormone, oestradiol and progesterone in peripheral serum and evidence that progesterone inhibits tonic LH secretion Endocrinology 101 807-817

Hyder SM, Stancel GM and Loose-Mitchell DS (1991) Presence of an cestradiol response region in the mouse c-fos oncogene Steroids 56 498-504

Hyman SE, Kosofsky BE, Nguyen TV, Cohen BM and Comb MJ (1993) Everything activates c-fos - how can it matter? NIDA Research Monographs 125 25-38

Johnson ML, Redmer DA and Reynolds LP (1997) Uterine growth, cell proliferation and $\mathrm{c}$-fos proto-oncogene expression throughout the estrous cycle in ewes Biology of Reproduction 56 393-401

Legan SJ and Karsch FJ (1979) Neuroendocrine regulation of the oestrous cycle and seasonal breeding in the ewe Biology of Reproduction 20 74-85

Loose-Mitchell DS, Chiappetta C and Stancel GM (1988) Oestrogen regulation of $c$-fos messenger ribonucleic acid Molecular Endocrinology 2 946-951

Nephew KP, Peters GA and Khan SA (1995) Cellular localisation of estradiolinduced c-fos messenger ribonucleic acid in the rat uterus: $c$-fos expression and uterine cell proliferation do not correlate strictly Endocrinology 136 3007-3015

Oldham CM and Lindsay DR (1980) Laparoscopy in the ewe: a photographic record of the ovarian activity of ewes experiencing normal or abnormal oestrous cycles Animal Reproduction Science 3 119-124

Perrot-Applanat M, Deng M, Fernandez H, Lelaidier C, Meduri G and Bouchard P (1994) Immunohistochemical localisation of oestradiol and progesterone receptors in human uterus throughout pregnancy: expression in endometrial blood vessels Journal of Clinical Endocrinology and Metabolism $78216-224$

Rivera VM and Greenburg ME (1990) Growth factor-induced gene expression: the ups and downs of c-fos regulation New Biology 2 751-758

Wathes DC and Hamon M (1993) Localisation of oestradiol, progesterone and oxytocin receptors in the uterus during the oestrous cycle and early pregnancy of the ewe Journal of Endocrinology 138 479-491

Weisz A and Bresciani F (1988) Oestrogen induces expression of c-fos and c-myc protooncogenes in rat uterus Molecular Endocrinology 2 816-824

Weisz A and Bresciani F (1993) Oestrogen regulation of proto-oncogenes coding for nuclear proteins Critical Reviews in Oncogenesis 4 361-388

Weisz A and Rosales R (1990) Identification of an oestrogen response element upstream of the human c-fos gene that binds the oestrogen receptor and the AP-1 transcription factor Nucleic Acids Research 18 5097-5106 